\title{
About the Photographs
}

The inclusion of recent photographs of displacement and violence in a book about la Violencia - a phenomenon that took place some fifty years earlier - may seem like a peculiar choice to many readers and so requires some explanation on the part of the author. When my editor, Valerie Millholland, first approached me about providing photographs to accompany this text, I demurred. Most of the existing images of the period were ones used to fan partisan hatred by one group against another and were almost without exception lurid representations that exploited the victims and titillated the viewer but contributed little to a deeper understanding of the complexity and human sorrow of violence. On a research trip to Medellín in June of 2001, as this book was about to enter into production, I happened upon an exhibit of works by Jesús Abad Colorado in the recently renovated Museo de Antioquia. I was so moved by his photographs of the current conflict in Antioquia and by the fact that nearly all of them were taken of displacements and violence occurring in the very same towns most affected by violence during the period I study in this book, that I resolved then and there to approach the photographer about the possibility of using some of his photographs to accompany this text. Little did I know that in addition to being an extremely gifted visual storyteller, Jésus Abad Colorado wrote narratives to accompany his photographs that in their basic outlines mirrored almost exactly the stories I recount here. It is the hope of both the photographer and myself that the conscious association of these images of recent violence in Antioquia with a written narrative of events taking place half a century earlier will invite readers to draw connections between past and present violence. Perhaps the anguish of recurrence these images bring to mind may lead to a greater understanding of the historical roots of conflict in Colombia. That is certainly our wish and motivation.-Mary Roldán

Jesús Abad Colorado received his journalism degree from the University of Antioquia in Medellín, Colombia. Between 1992 and May of 2001 he 
worked as a photojournalist for the regional daily newspaper, El Colombiano. His work has appeared regularly in national magazines and social research books. He coauthored the book Relatos e Imágenes, El desplazamiento Forzado en Colombia, and his photographs have been exhibited both in Colombia and abroad. 